\title{
Phorcotabanus cinereus (Wiedemann, 1821) (Diptera, Tabanidae), an Ornithophilic Species of Tabanid in Central Amazon, Brazil
}

\author{
Francisco Limeira-de-O liveira, José Albertino Rafael*, Augusto Loureiro Henriques*/+
}

Departamento de Química e Biologia, Centro de Estudos Superiores de Caxias, Universidade Estadual do Maranhão, Caxias, MA, Brasil *Coordenação de Pesquisas em Entomologia, Instituto Nacional de Pesquisas da Amazônia, Caixa Postal 478, 69011-970

Manaus, AM, Brasil

In Central Amazon, Brazil, the tabanid Phorcotabanus cinereus (Wiedemann) was recorded attacking the native duck Cairina moschata (Linnaeus) (Anseriformes, Anatidae). The flight and behavior of the tabanid during the attacks and the host's defenses were videotaped and analyzed in slow motion. The tabanid was recorded flying rapidly around the heads of the ducks before landing. Landing always took place on the beak, and then the tabanid walked to the fleshy caruncle on the basal part of the beak to bite and feed. Firstly the duck defends itself through lateral harsh head movements, and then, when it is being bitten, it defends itself by rubbing its head on the body, or dipping the head into water, when swimming. If disturbed, the fly resumed the same pattern of flight as before and would generally try to land again on the same host and bite in the same place. This feeding activity was observed predominantly between 9:30 am and 4:30 pm and always in open areas, near aquatic environments, from June 1996 to January 1997, the dry season in Central Amazon. To test the attractiveness of other animals to P. cinereus, mammals, caimans and domestic and wild birds were placed in suitable habitat and the response of P. cinereus observed. P. cinereus did not attack these animals, suggesting that this species has a preference for ducks, which are plentiful in the region.

Key words: Tabanidae - Phorcotabanus cinereus - haematophagy - ducks - Anatidae - Amazon Basin - Brazil

Tabanids are cosmopolitan flies, occurring in temperate and tropical regions. In the neotropics, they are found in almost every habitat, from mangroves and beaches to the snow line of the Andes, and from the extreme deserts of Peru and Chile to the tropical forests. Most tabanids have a definite habitat preference, with the exception of a few species with large distribution occurring in open agricultural lands. This aspect of their biology has been poorly studied (Fairchild 1981). At present, 1,172 species are known for the Neotropical region (Fairchild \& Burger 1994) and less than $10 \%$ have been studied from the biological, ecological or behavioral points of view.

Tabanids originated in the Mesozoic, 180 million years ago, and diversified along with mammals, their primary hosts (Downes 1971). Hematophagous species use mainly mammals, such as equines, swine, bovines, tapirs, sloths and man as protein sources, but may also attack crocodilians and snakes (Fairchild 1986). Most of the information on food habits and host preferences comes from experiments with domestic animals, mainly equines and bovines, little is known about the preference for wild hosts.

Experiments with domestic animals are important because they provide basic information on the behavior, seasonality, and density of tabanids. Gorayeb (1985) showed, in Oriental Amazonia, that different tabanid spe-

Financial support: PPI - 3070 (MCT/INPA)

${ }^{+}$Corresponding author. Fax: +55-92-643.3206. E-mail: loureiro@inpa.gov.br

Received 7 November 2001

Accepted 9 May 2002 cies feed on different areas of the host's body, at different times during the day and in different periods of the year, a strategy to avoid interspecific competition.

Although mammalian blood is the usual protein source for tabanids, there are some observations of attacks on reptiles. Austen (1912) described a tabanid species collected upon African crocodiles; Surcouf (1923) described one species collected on the monitor lizard, Varanus griseus, in the Algerian desert; Austen (1920) registered attacks to a marine turtle from the Seychelles Archipelago; Curran (1934) registered attacks to land tortoises from the Galapagos Islands; Philip (1976) registered attacks to land turtles and marine turtles in the Galapagos, turtles in the USA, alligators and boa snakes in Colombia and Boa sp. in a Zoo in Panama; Medem (1981) complemented the information previously published by Philip (1976) on the attacks of tabanids on alligators in Colombia. Philip (1986) registered four species attacking the anaconda snake, Eunectes murinus, in the Peruvian Amazonia. Henriques et al. (2000) registered four species attacking the common caiman, Caiman crocodilus, in Central Amazonia.

Studies with other potential hosts are rare. There are no records of attacks on amphibians and information about attacks on birds is scarce. The only known study is from Bennett (1960), who registered, during two years, a few specimens of Chrysops attacking crows (Corvus sp.) in the Algonquin Park, Ontario, Canada. Bennett observed that some specimens of Chrysops and Tabanus were attracted to ducks (Anatidae). Ducks generally eat horseflies before they land to feed. In his experiment, Bennett tied the duck's legs, to enable the observation of a potential success on blood sucking by the horseflies.

Ecological and behavioral studies of horseflies and their interaction with domestic animals are necessary in 
the Neotropical region, and especially in Central Amazonia, where the process of human occupation is accelerating.

The objective of the present study is to supply information on the seasonality, habitat preferences, diurnal activity, attack behavior, duration of blood feeding, host defense behavior and potential hosts of Phorcotabanus cinereus (Wiedemann, 1821). This species is widely distributed in South America, occurring from the East of the Andes to French Guiana, Brazil (Amazon Basin and Maranhão, Rio Grande do Norte, Santa Catarina, Minas Gerais and Mato Grosso states), Ecuador, Peru, Bolivia (Santa Cruz), Colombia (Meta) and Northern Argentina (Chaco and Salta) (Fairchild \& Burger 1994).

\section{MATERIALS AND METHODS}

Collections and observations were performed in two sites on the right side of the AM-010 road, Manaus, Brazil. The first site (site 1) was a small ranch at $\mathrm{km} 30$ $\left(02^{\circ} 51^{\prime} 47^{\prime}\right.$ 'S $-59^{\circ} 55^{\prime} 55^{\prime}$ 'W), and the second (site 2$)$ was the forest reserve Adolpho Ducke, owned by the Instituto Nacional de Pesquisas da Amazônia (Inpa), at km 21 $\left(02^{\circ} 55^{\prime}\right.$ to $03^{\circ} 00^{\prime} \mathrm{S}$ and $59^{\circ} 55^{\prime}$ to $\left.59^{\circ} 59^{\prime} \mathrm{W}\right)$. The first site has three artificial lakes, two for the culture of fish and the domestic duck Cairina moschata (Linn.) (Aves: Anatidae). The second site was used as control, since it has no domestic ducks. Both sites are covered by nonflooded evergreen rain forest (Ribeiro et al. 1994). The climate is warm and humid, with mean annual precipitation of ca. 2,478 mm concentrated between December and May, and mean annual temperature is about $27.6^{\circ} \mathrm{C}$ (Köppen 1948).

Seasonality of $P$. cinereus was determined with fly interception traps on both experimental sites. At site 1 (lake

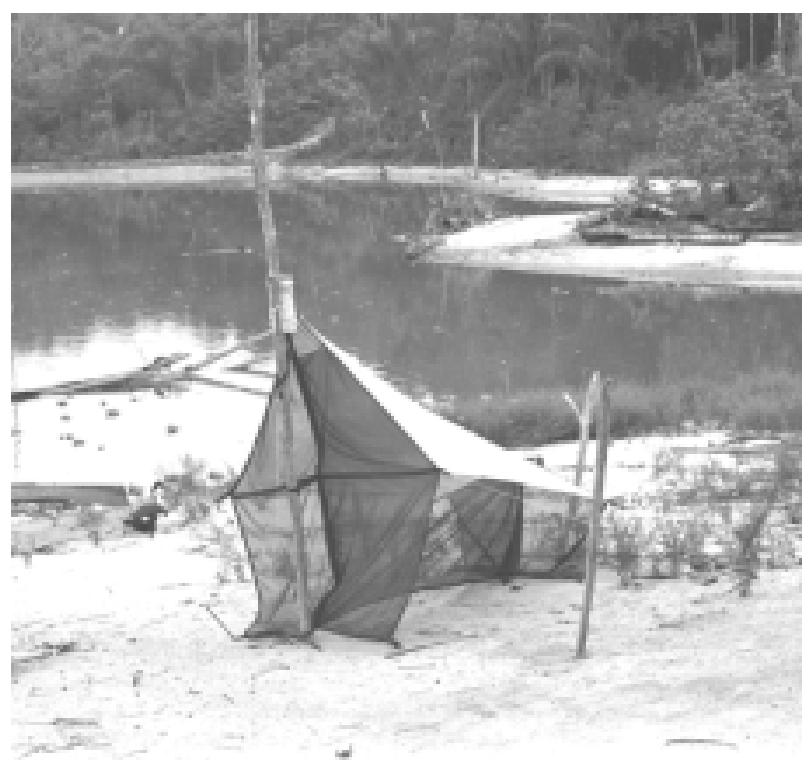

Fig. 1: panoramic view of the experimental area on site 1 (Tropical Life Ranch), AM 010 Road, km 30, the Malaise trap on the first plane and the artificial lake for duck raising (lake 2) on the background.
2), traps were installed from June 1996 to June 1997 (Fig. 1), and at site 2 from August 1996 to June 1997, and examined each week. Tabanids were identified and deposited at Inpa.

To determine the preferential habitat of $P$. cinereus, one trap was installed in each of four habitats: (1) forested area on site 1; (2) open anthropic area on site 1; (3) forested area on site 2 and (4) open anthropic area on site 2. In forested habitats, the traps were at first installed 500 $\mathrm{m}$ from the anthropic clearings, and then moved to the border of the clearings, 3 to $5 \mathrm{~m}$ from them. Four months after the beginning of the experiments, traps were moved again and installed over small streams, as these are natural corridors for insects. Some ducks were transferred from the clearing to the forest, to determine the occurrence of tabanid attacks to ducks in this habitat. Several sweepings with an entomological net were made to determine the incidence of tabanids around lake 2.

Diurnal activity was determined through direct observations on the duck raising lake and hourly examination of Malaise traps on site 1, from 5:30 to 18:30 h, during two days per week from July to November 1996.

Analysis of the attack behavior and host defense were done with direct observations on site 1 and videotaped for analysis in slow motion. Traps were deactivated when behavioral observations were being done.

Duration of blood feeding was timed manually and derived also from the tapings $(n=10)$. As the tabanid landed on the duck, it was captured and immobilized not to disturb the fly and interrupt blood sucking.

Hosts of $P$. cinereus were determined through an experiment in which horses, Equus caballus Linn. and black caiman, Melanossucus niger (Spix), were placed around lake 2 in site 1 from September 1996 to January 1997 and the responses of the fly observed. Other potential hosts, free in the experimental area, cows, Bos taurus Linn., domestic dog, Canis familiaris Linn., guineafowl, Numida meleagris (Linn.), domestic chicken, Gallus gallus Linn., and humans, were also observed.

Horse and black caiman, potential hosts of tabanids were transferred and maintained for some days far from the influence of the duck raising, on lake 3 , roughly 1,000 $\mathrm{m}$ from lake 2, were the other experiments took place. Finally, a few ducks were transferred to lake 3 , for direct observation.

Precipitation data were obtained from Inpa meteorological station on site 2 .

\section{RESULTS AND DISCUSSION}

Seasonal occurrence - P. cinereus was registered from June 27, 1996 to January 30, 1997, and reappeared on June 12, 1997.

Occurrence of $P$. cinereus coincided with the months of lower precipitation in the region (Fig. 2). The greatest abundance occurred between July and October. During June, the beginning of July, November, December and January, $P$. cinereus had a sparse occurrence. The period of flight activity of this species was the same of the majority of the Amazonian tabanids (Rafael \& Charlwood 1980, Rafael 1982, Gorayeb 1985). 


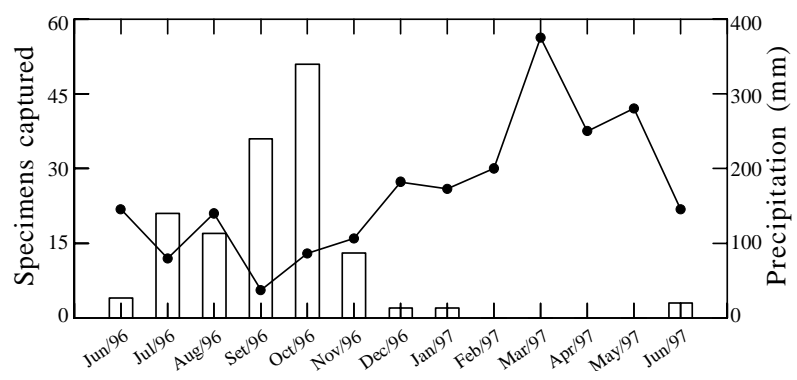

Fig. 2: number of individuals of Phorcotabanus cinereus captured with a Malaise trap on lake 2 (site 1) and mensal precipitation means registered by the meteorological station on the Adolpho Ducke Reserve. On July 1996 the trap was inactive during five days, on August 1996 during eight days and on September 1996 during four days. The continuous line is the precipitation data.

Habitat - P. cinereus was registered only in the open areas of both study sites, with a continual occurrence during the flight period. There was no register in the forested areas.

Occurrence of $P$. cinereus only in open areas indicates a preference for this habitat. It was always collected near the lakes and small streams, indicating that these way be the habitat for the development of larvae. These are also the habitat of the regional duck.

Host - Horses, which are generally good hosts for tabanids (Gorayeb 1985), were inefficient to collect $P$. cinereus. Other potential hosts, Melanosuchus niger, dogs, bovine cattle, chickens, guineafowl and man, were never attacked. $P$. cinereus attacked only the regional ducks. Henriques et al. (2000) also failed to capture $P$. cinereus in site 2 , using the common caiman, $C$. crocodilus.

P. cinereus was registered on site 2 , where there is no raising of regional ducks, indicating that it may be attacking other Anatidae species or other birds in primary forests.

Diurnal activity - P. cinereus was active from 9:30 to 16:30 h, during the period of greater insolation. Contrary to most tabanid species, which attack mammals and have restricted and definite periods of attack (Rafael \& Charlwood 1980, Gorayeb 1985), P. cinereus attacks its host without competitors, and therefore can use a larger period of time. The period of greater activity was from 12:00 to $14: 00 \mathrm{~h}$. Only one register was made at 7:30 h.

Attack behavior - The fly comes near the duck flying fast and circularly, in both clockwise and anti-clockwise directions, around the duck's head. The flight direction changes several times before landing. The duck tries to catch the fly before it lands, but only rarely it succeeds and eats it. The fly always lands on the beak and walks to the caruncle, where it starts to bite (Fig. 2), intensely disturbing the bird.

The fast and circular flight around the head makes the capture by the duck difficult. Once the fly reaches the place it chooses to bite, it cuts the skin with the mandible blades, which causes pain and makes the host react, trying to remove the fly. If disturbed, the tabanid generally attacks again in the same place as before, using the same sequence of movements. After several trials, the fly gets its meal and defense movements of the host do not disturb it anymore, as the pain ceases after the cut is done and the fly is only sucking the blood. McKeever and French (1997) attribute the cessation of pain to the production of anesthetic substances by some flies. Initial action of these substances may facilitate later attacks on the same area.

Duration of the blood meal - Duration of the blood meal was 10 to 12 minutes $(n=5)$. The fly's abdominal pleura became distended and reddish by the ingested blood (Fig. 3).

Host's defense behavior - When attacked on land, the duck defends itself through harsh lateral head movements. If it cannot remove the fly with the head movements, it rubs the head on the body or rubs the nails on the fly. When attacked on water, the duck also tries the head movements and if not successful, dips its head into the water. Occasionally, when ducks are close to each other, if one of them notes a fly landed on a close duck, it catches and eats it.

Results indicate that $P$. cinereus has specificity for birds, specially the regional duck, C. moschata, both species having the same distribution and the same habitat preference.

In the Central Amazonia, near Manaus, P. cinereus was observed attacking the domesticated regional duck, C. moschata. This represents the first register of horseflies naturally attacking birds in the world. It is also the first register of a horsefly attacking a small host.

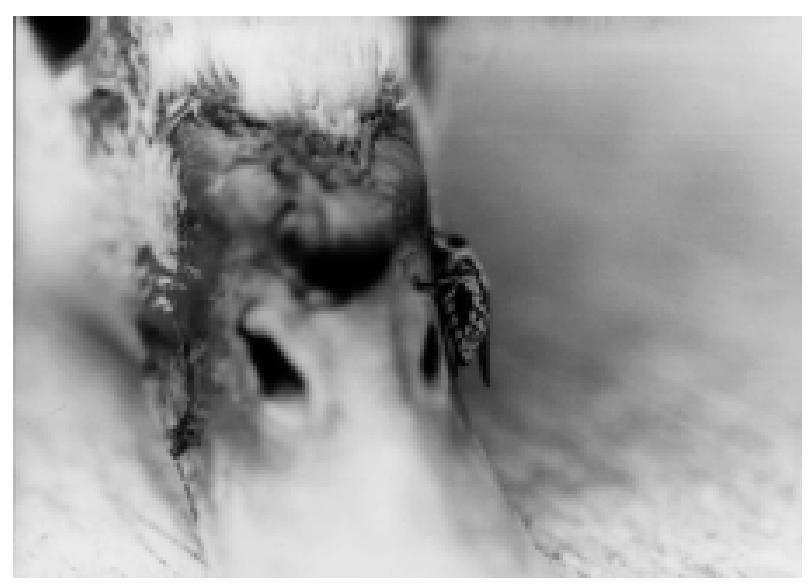

Fig. 3: frontal view of the head of Cairina moschata, with Phorcotabanus cinereus feeding on it.

I is necessary to point out that the process of deforestation of large areas of Amazonian forests is a reality. Therefore, it is necessary to elucidate the ecological characteristics of tabanids, to be able to predict the consequences of the activities of these insects, as they will probably constitute pests of animals of economic interest, causing losses to the animal protein production.

The need for animal protein is growing in Amazonia, and consequently the raising of cattle and birds like the 
regional duck is rapidly proliferating. Some tabanid species will have a growth in their hosts, causing an increase of their populations (Gorayeb 1993).

Finally, we recommend to duck raisers the use of Malaise traps, which are simple, cheap and efficient, to reduce the population of P. cinereus, especially from July to November.

\section{REFERENCES}

Austen E 1912. New African species of Tabanus. Bull Ent Res 2: 279-290.

Austen E 1920. The Percy Sladen Trust expedition to the Indian Ocean in 1905 and 1907-1909. Bull Ent Res 11: 43-45.

Bennett GF 1960. On some ornithophilic blood-sucking Diptera in Algonquin Park, Ontario, Canada. Can J Zool 38: 377389.

Curran H 1934. The Templeton Crocker expedition of the California Academy of Sciences, 1932. Proc Calif Acad Sci 21: 147-172.

Downes JA 1971. The ecology of blood-sucking Diptera: an evolutionary perspective. In AM Fallis, Ecology and Physiology of Parasites, Univ. of Toronto Press, Toronto, p. 232-258.

Fairchild GB 1981. Tabanidae. In SH Hurlbert, C Rodriguez, ND Santos (eds), Aquatic Biota of South America, Part 1, Arthropoda, San Diego State Univ, San Diego, CA, p. 290-301.

Fairchild GB 1986. The Tabanidae of Panama. Contr Amer Ent Inst 22: 1-139.

Fairchild GB, Burger JF 1994. A catalog of the Tabanidae (Diptera) of the Americas South of the United States. Mem Am Entomol Inst 55: 1-249.

Gorayeb IS 1985. Tabanidae (Diptera) da Amazônia Oriental: Sazonalidade, Ataque e Estratificação Arbórea, PhD The- sis, Inpa/FUA, Manaus, 205 pp.

Gorayeb IS 1993. Tabanidae (Diptera) da Amazônia. XI. Sazonalidade das espécies da Amazônia oriental e correlação com fatores climáticos. Bol Mus Para Emílio Goeldi Sér Zool 9: 214-281.

Henriques AL, Ferreira RLM, Vidal JF, Rafael JA 2000. Betrequia ocellata (Diptera: Tabanidae: Rhinomyzini) blood feeding on Caiman crocodilus (L.) (Crocodylia: Alligatorydae) in Manaus, Brazil. Rev Bra Zool 17: 609-613.

Köppen W 1948. Climatologia com un Estudio de los Climas de la Tierra, Fondo de Cultura Economica-Pánuco, Mexico, $479 \mathrm{pp}$.

McKeever S, French FE 1997. Fascinating, beautiful blood feeders deer flies, the Tabanidae. Amer Entomol 43: 217-226.

Medem F 1981. Horse flies (Diptera: Tabanidae) as ectoparasites on caimans (Crocodylia: Alligatoridae) in Eastern Colombia. Cespedesia 10: 123-147.

Philip CB 1976. Horse flies, too, take some victims in coldblood as on Galapagos Isles. Pan-Pac Entomol 52: 84-88.

Philip CB 1986. A collection of four species of tabanid flies taken from an anaconda snake in Peru in May, 1984. PanPac Entomol 62: 23.

Rafael JA 1982. Ocorrência sazonal e abundância relativa de Tabanidae (Diptera) no Campus Universitário, Manaus, Amazonas. Acta Amazonica 12: 225-229.

Rafael JA, Charlwood JD 1980. Idade fisiológica, variação sazonal e periodicidade diurna de quatro populações de Tabanidae (Diptera) no Campus Universitário, Manaus, Brasil. Acta Amazonica 10: 907-927.

Ribeiro JELS, Nelson BW, Silva MF, Martins LS, Hopkins M 1994. Reserva Florestal Ducke: diversidade e composição da flora vascular. Acta Amazonica 1: 19-30.

Surcouf J 1923. Diptères nouveaux ou peu connus. Ann Soc Ent Fr 41: 237-244. 